\title{
Tumor Endothelial Cells
}

\author{
Andrew C. Dudley \\ The Department of Cellular and Molecular Physiology, The University of North Carolina at Chapel Hill, Chapel \\ Hill, North Carolina 27599; Lineberger Comprehensive Cancer Center, Chapel Hill, North Carolina 27599; \\ and McAllister Heart Institute, Chapel Hill, North Carolina 27599 \\ Correspondence: acdudley@med.unc.edu
}

The vascular endothelium is a dynamic cellular "organ" that controls passage of nutrients into tissues, maintains the flow of blood, and regulates the trafficking of leukocytes. In tumors, factors such as hypoxia and chronic growth factor stimulation result in endothelial dysfunction. For example, tumor blood vessels have irregular diameters; they are fragile, leaky, and blood flow is abnormal. There is now good evidence that these abnormalities in the tumor endothelium contribute to tumor growth and metastasis. Thus, determining the biological basis underlying these abnormalities is critical for understanding the pathophysiology of tumor progression and facilitating the design and delivery of effective antiangiogenic therapies.

\section{INTRODUCTION: BLOOD VESSEL STRUCTURE AND FUNCTION}

\section{Endothelial Cells, Smooth Muscle Cells, and Basement Membrane}

continuous layer of endothelial cells (ECs)
and lines the heart, arterioles, capillaries, veins,
lium as a dynamic, functioning organ (Aird
2006). The endothelium is highly specialized
and varies considerably from tissue to tissue
and organ to organ. For example, the kidney's
glomerulus is a fenestrated capillary tuft that fil-
ters blood to form urine whereas the blood-
brain barrier endothelium is characterized by
junctional proteins that restrict passage of sol-
utes into the central nervous system. Irrespec-
tive of its tissue of origin, the endothelium
performs several critical functions including
regulating the passage of nutrients, oxygen, and other solutes from the bloodstream to the tissues, regulating the flow of blood by maintaining a nonthrombogenic surface, and controlling the trafficking of leukocytes into and out of the tissues.

The structure of the normal vascular endothelium is hierarchical. Arteries branch to arterioles, which then form thin-walled capillaries. Smooth muscle cells (SMCs) wrap around large vessel endothelium and provide vessel stability and paracrine/juxtacrine cues to the underlying ECs. SMCs also express contractile proteins that regulate vessel diameter. The finer capillaries are surrounded by perivascular cells called pericytes that also provide vessel stability (Hirschi and D'Amore 1996). Genetic depletion of PDGFB (a major pericyte growth factor) or its receptor results in loss of pericytes, vessel leakage, and hemorrhage (Hellström et al. 2001). All blood vessels have a proteinaceous

Editors: Michael Klagsbrun and Patricia D'Amore

Additional Perspectives on Angiogenesis available at www.perspectivesinmedicine.org

Copyright (C) 2012 Cold Spring Harbor Laboratory Press; all rights reserved; doi: 10.1101/cshperspect.a006536

Cite this article as Cold Spring Harb Perspect Med 2012;2:a006536 
A.C. Dudley

basement membrane or extracellular matrix (ECM) usually rich in collagens, laminin, and fibronectin. The ECM provides support and stability but can also signal through interactions with integrins expressed on the EC surface (Hynes 2009).

\section{HOW NEW BLOOD VESSELS ARE FORMED}

Blood vessels are dynamic structures. New vessels are formed when needed (e.g., during wound healing), whereas old ones are pruned away. Neovascularization occurs by three main processes: angiogenesis, vasculogenesis, and intussusception. These same processes are recapitulated during pathophysiological angiogenesis found in tumors; however, the key regulatory pathways controlling blood vessel growth, branching, and morphology in tumor vessels are faulty. In addition, some of the same processes regulating blood vessel patterning and growth during development of the embryo reappear in tumor angiogenesis (Baudino et al. 2002). A fourth process termed arteriogenesis involves an increase in the diameter of preexisting arterioles that remodel and form collaterals, but this process is not welldescribed in the tumor vasculature and is not discussed here.

\section{Angiogenesis}

In the adult, new blood vessels arise from preexisting ones by angiogenesis. Angiogenesis is characterized by dissolution of the ECM, EC mitoses, and sprouting. Vascular patterning is controlled by gradients of angiogenic factors that guide and unite immature endothelial tip cells (Gerhardt et al. 2003). For example, a VEGF/Dll4/notch axis is a key regulator of vessel sprouting (Hellström et al. 2007). Surprisingly, the neuronal and vascular systems share common guidance cues (Klagsbrun and Eichmann 2005). An intrinsic pathway using local expression gradients of sFLT-1 that directs emerging sprouts away from the parent vessel was recently proposed (Chappell et al. 2009). After a new vessel is formed, the basement membrane and pericytes add stability to the nascent vascular tree. Angiogenesis is a tightly controlled, self-regulating, reversible process. For example, the formation of new blood vessels has evolved so that products generated during ECM remodeling can inhibit EC proliferation and migration, thus fine-tuning the formation of new vascular structures (Kalluri 2003).

\section{Vasculogenesis}

In contrast to angiogenesis, vasculogenesis occurs mainly during development when progenitor cells (angioblasts) committed to the vascular lineage differentiate to form an immature vascular plexus in the embryo (Jin and Patterson 2009). In the yolk sac, a bi-potent stem cell called the hemangioblast is thought to differentiate to form both hematopoietic cells and ECs (Lacaud et al. 2004). Aggregates of mesodermal cells within the yolk sac form a blood island that gives rise to ECs at the periphery and hematopoietic cells in the center. Shared expression of a number of different markers supports the concept that ECs and hematopoietic cells have a common ancestor; however, unequivocal evidence for the existence of the hemangioblast is still debated. Strong evidence for the generation of hematopoietic cells through hemogenic endothelium was recently presented (Lancrin et al. 2009). Bona fide ECs for postnatal vasculogenesis can be isolated from the peripheral blood of adults, but the origin of these circulating ECs remains elusive (Yoder et al. 2007; Melero-Martin et al. 2008). Furthermore, the role of circulating ECs in tumor angiogenesis remains controversial.

\section{Intussusceptive Angiogenesis}

An alternative and rapid mechanism for a new vessel to form is through intussusceptive angiogenesis (IA). During IA, the capillary wall forms transvascular tissue pillars and extends into the lumen splitting the vessel on the long axis while maintaining intact circulation (Burri et al. 2004). Because the process occurs by reorganization of existing cells, IA allows for the rapid increase in capillary density in the developing embryo and perhaps in tumors (Patan et al. 
Tumor Endothelial Cells

2001). For example, intermittent changes in blood flow and sheer stress in the tumor vasculature may induce remodeling and IA on the time scale of minutes (Patan et al. 1996). Although IA does occur in the vasculature of growing tumors, it has been largely unexplored as a mechanism for creating new tumor blood vessels or as a process that could be inhibited to thwart tumor growth.

\section{TUMOR BLOOD VESSELS APPEAR ABNORMAL IN VIVO}

It was noticed long ago that tumor blood vessels were abnormal morphologically. Threedimensional scanning electron microscopy of vascular plaster casts showed chaotic networks of tortuous endothelium lacking the normal hierarchical arrangement of artery-arteriolecapillary (Warren et al. 1978; Konerding et al. 1999). Poor tumor vessel stability may be caused by defects in pericytes, which are in lower abundance and are loosely attached compared to normal vessels (Baluk et al. 2005). These changes in vessel stability can affect blood flow. For example, some tumor vessels are not perfused with blood altogether, whereas others have chaotic blood flow that may reverse directions. New techniques have allowed for accurately measuring blood flow in tumors at the single-capillary resolution (Kamoun et al. 2010). The density of blood vessels may increase in bursts during early tumor formation while decreasing in larger tumors when tumor growth outpaces the rate of blood vessel formation. Poor tumor vessel quality rather than vessel abundance may therefore be a better prognostic indicator of tumor progression or perhaps metastasis. Dvorak has nicely classified tumor vessels into six types based on their morphology (Nagy et al. 2009). For example, "mother vessels" are greatly enlarged, tortuous, and thinwalled, whereas "glomeruloid microvascular proliferations" are tangles of tiny vessels with irregular ordered pericytes and multilayered basement membranes.

Since those first images of the tumor vasculature were made in the 1970s, advances in microscopy have allowed for images of tumor vessels in stunning detail (McDonald and Choyke 2003). Notably, these images confirm morphological abnormalities at all levels of the vascular tree: the endothelium, pericytes, and basement membrane. Here we will only focus on those abnormalities described specifically in the endothelium. Unless referenced otherwise, the abnormalities described below can generally be characterized as first reported by McDonald and colleagues and are depicted in Figure 1 (Hashizume et al. 2000).
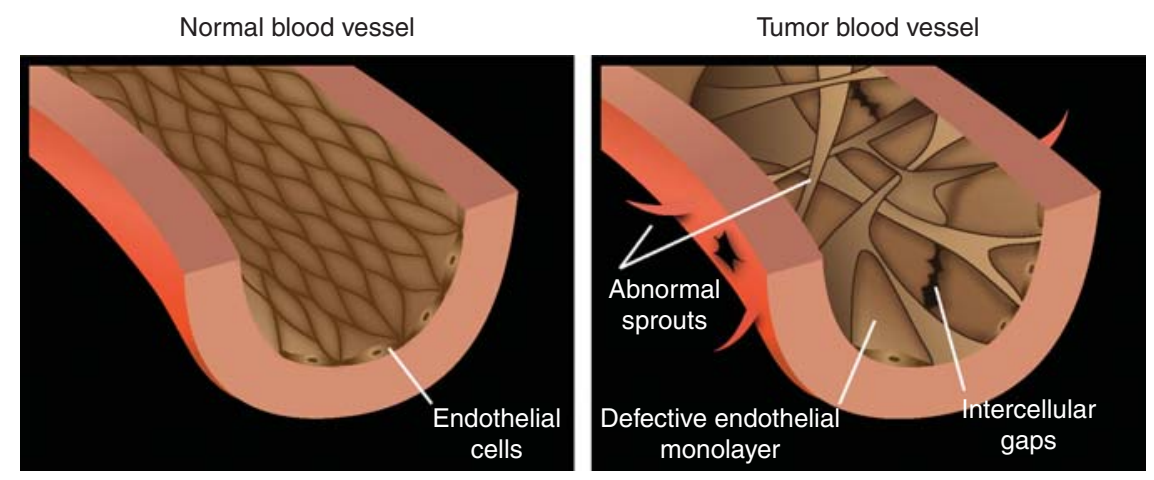

Figure 1. Abnormalities in tumor endothelial cells. In a normal blood vessel (shown at left) a monolayer of endothelial cells form tight junctions with one another without overlapping at the margins. In contrast, TECs branch and sprout excessively resulting in a defective endothelial monolayer and loss of their normal barrier function. These branches may extend across the lumen and overlap with neighboring endothelial cells. Changes in endothelial shape result in intercellular gaps or holes that leak fluid, blood, and fibrin into the surrounding tissue. 
A.C. Dudley

\section{Defective Endothelial Monolayer}

In normal tissues the ECs form a continuous and uniform monolayer with few cytoplasmic projections. Tumor endothelial cells (TECs) are of irregular shape and size; they have ruffled margins and long, fragile cytoplasmic projections extending outward and across the vessel lumen. The tips of some branched TECs may penetrate the lumen creating openings or small intercellular gaps in the vessel wall. These openings allow extravasated erythrocytes to pool at the periphery of tumor blood vessels forming "blood lakes" which are not anastomosed with the vasculature. The appearance of tumor endothelium is described as "mosaic" because of spotty CD31 immunoreactivity in vivo (di Tomaso et al. 2005). The reasons for this are twofold: ultrastructural analysis of the tumor vessel lining shows that individual TEC lack CD31 expression and in other areas of the vessel wall the TECs are absent altogether. Where there are gaps between adjacent TECs, blood can make direct contact with the exposed basement membrane. Nearby tumor cells may also fill these exposed gaps (Chang et al. 2000). Tumor cells that express VE-cadherin, fill in these gaps, and masquerade as endothelium have been reported (Maniotis et al. 1999), but this topic remains controversial (McDonald et al. 2000).

\section{Large Intercellular Openings and Holes}

Similar to small intercellular gaps between neighboring TEC, larger openings $(\sim 1.5 \mu \mathrm{M})$ in the walls of tumor blood vessels are also visible by scanning electron microscopy. These larger openings lack the structural features, including the finger-like projections often observed in inflamed endothelium that could mediate their closure. Furthermore, high TEC turnover and motility may not allow for proper formation of intercellular junctions and basement membranes resulting in these larger holes. Transcellular holes $(\sim 0.5 \mu \mathrm{M})$, fenestrae, and channels are also common in the tumor vasculature. Together, these small endothelial gaps and larger openings are probably responsible for hemorrhage and plasma leakage observed in most tumors. Holes in the tumor vasculature could also act as a conduit for the passage of tumor cells into the circulation.

\section{Abnormal Sprouts}

Tumor vessels have thin cytoplasmic projections extending across the vessel lumen. These projections resemble tip-like filopodia observed during intussusceptive growth but they may overlap with one another and form loose connections. The origin of these sprouts may be the oxygen seeking tip cells at the leading edge of sprouting vessels in hypoxic regions of the tumor microenvironment. Carmeliet and colleagues recently proposed a molecular basis for these abnormal sprouts (Mazzone et al. 2009). For example, tip cells of tumor vessels in mice haploinsufficient for the oxygen sensor PHD2 appear quiescent and adjust their shape and phenotype to restore oxygen supply. Molecular therapies targeting PHD2 may "normalize" tumor vessels improving perfusion while ameliorating the hypoxia that can promote invasion and metastasis (Sullivan and Graham 2007).

\section{What Are the Causes of These Abnormalities?}

Tumors are caricatures of a dysfunctional “organ." For example, metabolic pathways are corrupted, tumor cells deprive nearby tissues of nutrients, there is a buildup of toxic waste products such as lactate resulting in acidosis, and there are areas of nonperfusion resulting in focal regions of hypoxia. If one considers that the vasculature is a supply line for oxygen and nutrients but also a conduit for the removal of waste products, then abnormalities in the blood vessels themselves are a major contributor to the abnormal microenvironment in tumors. Not only do cancer cells thrive in this environment, but selection pressure created by these microenvironmental bottlenecks may actually contribute to their propagation (Merlo et al. 2006).

As an example, most tumors are characterized by the expression of high concentrations of VEGF-A. VEGF alone is a potent vasodilator that can promote fluid leakage and high interstitial pressures, abnormal branching morphogenesis, and small gaps and fissures in the 
vasculature (Nagy et al. 2007). Thus, chronic VEGF stimulation in tumors promotes sprouting and excessive branching of tip cells leading to irregularities in the TEC monolayer and loss of barrier function. Irregularities in the TEC lining surrounding these vessel protrusions impairs blood flow resulting in hypoxia and hypoperfusion. Tumor vessels are also squeezed and compressed by overlying tumor cells, which creates biomechanical tension, strain, and changes in blood flow (Padera et al. 2004). This chaotic pattern of blood flow can alter endothelial shape, size, and differentiation perhaps through aberrant expression of flow-mediated transcription factors (De Val and Black 2009). Notably, endothelial dysfunction in tumors is not a dead end. All cell types found within the perivascular niche either in direct contact with the endothelium or dependent on soluble vascular-derived factors (e.g., pericytes and trafficking leukocytes) for their growth and differentiation might be adversely affected.

\section{STUDIES OF ISOLATED TUMOR ENDOTHELIAL CELLS}

For many years, it was assumed that TECs were similar to their normal counterparts irrespective of the obvious morphological abnormalities of tumor blood vessels in situ. In fact, the theoretical success of antiangiogenic (specifically antiendothelial) strategies in cancer depends to some extent on TECs remaining stabile and not altering their phenotype over time. However, recent studies have shown that TEC are more complex and labile than expected challenging the assumption that TEC are normal. Collectively, these studies show morphological, pathophysiological, cytogenetic, epigenetic, and gene expression changes in the TEC pool. Despite this new knowledge, overall our understanding of TEC biology has been hampered by several technical limitations, which are described below.

First, a common method for isolating "pure" populations of TECs is immunomagnetic separation (IMS) with antibody-coated beads. Common cell-surface markers used to isolate TEC are CD31 (Hida et al. 2004), ICAM-2 (Dudley et al. 2008a), and CD146 (St Croix et al. 2000). However, these markers are shared by endothelial cells from virtually all vascular beds (capillary, venous, arterial, and lymphatic); thus, heterogeneity in the isolated population of TECs is unavoidable. The fidelity of IMS is also not $100 \%$ so contamination by fibroblasts and tumor cells is problematic. Diphtheria toxin has been successfully used to eliminate human tumor cells from cultures of mouse TECs (Arbiser et al. 1999; Hida et al. 2004). The most proficient way to ensure purity of isolated TECs is to prepare clonal populations, but this can be challenging because ECs plated at clonal density will often undergo senescence. Laser capture microdissection (LCM) is also used to isolate TECs but the cells cannot be cultured. Similar to IMS, there are problems with contaminating pericytes and tumor cells that copurify with TECs.

Second, the conditions for culturing TECs in vitro are not well defined. TECs may be adapted to the tumor microenvironment (e.g., chaotic blood flow, acidosis, hypoxia, nutrient deprivation), which cannot be faithfully replicated in vitro. There may be unique media requirements and combinations of growth and attachment factors. For example, in one study, the use of oncofetal fibronectin was necessary to maintain the phenotype of TECs isolated from Lewis lung carcinoma (LLC) (Allport and Weissleder 2003). Thus, following phenotypic drift, TECs placed in culture may no longer resemble TECs in vivo.

Despite the challenges, several groups have isolated and characterized (i.e., high-throughput gene expression analyses) TECs from human tumors and from tumors implanted in mice. These studies typically fall into two categories: those that isolated and characterized TECs that were never cultured, and those that used isolated and culture expanded TECs for their analyses. Other studies have attempted to create or identify "TEC" lines in vitro by culturing normal ECs with tumor cell conditioned media or by screening mouse cell lines for the expression of markers already known to be expressed by TECs (Walter-Yohrling et al. 2004; 
A.C. Dudley

Hellebrekers et al. 2007). Although there is some value to these approaches, the use of surrogates cannot substitute for isolating TECs from the native tumor microenvironment.

Freshly Isolated Tumor Endothelial Cells That Were Never Cultured

St. Croix published the first comprehensive genetic screening of human TECs from malignant colorectal tissues (St Croix et al. 2000). The investigator's used serial analysis of gene expression (SAGE) to identify 46 transcripts specifically elevated in TECs. Nine novel TEC transcripts were identified and named tumor endothelial markers (TEMs). The hope was that TEMs might be unique to TECs and therefore suitable targets or markers of the tumor vasculature. However, subsequent studies suggest that some TEM expression may not be restricted to TECs. TEMs 1 and 5 were also found in some normal vascular beds (Seaman et al. 2007). In one study, TEM1 was detected in fibroblasts and perivascular cells but not endothelium (MacFadyen et al. 2007). Another study showed ubiquitous TEM1 expression in developing tissues (Opavsky et al. 2001). TEM7 expression was found in the brain (Lee et al. 2005) and some osteosarcoma cell lines (Halder et al. 2009). TEM8 (the anthrax toxin receptor) is also expressed in the vasculature of the developing corpus luteum (St Croix et al. 2000). Despite TEM8 expression in some normal tissues, its utility as a marker or target in tumor vessels is still being investigated. For example, TEM8 knockout mice showed no effect on physiological angiogenesis in the retina or healing wounds but the growth of some tumor types was delayed in the TEM ${ }^{-/-}$background (Cullen et al. 2009).

SAGE or subtractive hybridization was also used to analyze gene expression in TECs of human brain glioma (Madden et al. 2004; Pen et al. 2007), ovarian cancers (Buckanovich et al. 2007; Lu et al. 2007), and breast cancers (Parker et al. 2004; Bhati et al. 2008) isolated by IMS or LCM. Aird has nicely collated the transcriptional profiling results of TECs from multiple studies and multiple tumor types
(Aird 2009). Only a few overexpressed genes were shared by different tumors including MMP9 (ovary and breast), HEYL (breast and colon), and SPARC (breast and colon and brain). The majority of genes were limited to one tumor type or to invasive tumors. For example, HEYL was restricted to invasive breast tumors (Parker et al. 2004). Thus, there may be tumor stage and tumor-type-specific differences in the TEC pool. In support of this possibility, Hoffman used phage display and found peptides that homed to the neovasculature of premalignant lesions but not of malignant skin tumors (Hoffman et al. 2003). Similarly, tumor stage and tumor site-specific (orthotopic vs. subcutaneous) peptides were identified in the vasculature of pancreatic tumors (Joyce et al. 2003).

High-throughput screens to identify unique proteins expressed on the surface of TECs have also been used. One approach uses colloidal silica nanoparticles to coat the luminal surface of the endothelium followed by subcellular fractionation and subtractive proteomic mapping. Schnitzer and colleagues used this technique and found amino peptidase-P and annexin A1 as selective targets for the lung tumor vasculature (Oh et al. 2004). Furthermore, ${ }^{125}$ I-labelled annexin A1 antibodies accumulated in the lung tumor vasculature, destroyed tumors and prolonged survival in tumor-bearing rats.

Recently, epigenetic and miRNA screens were used to further characterize TECs at the molecular level. For example, Grover and colleagues found methylation silencing of the GSTP1 and RAR $\beta 2$ promoters in prostate TEC isolated by LCM (Grover et al. 2006). Eighty-one genes were silenced in normal ECs cultured in tumor cell-conditioned mediumsome of these genes were confirmed in TECs isolated by LCM (Hellebrekers et al. 2007). A regulatory miRNA (miR-296), which controls expression of the growth factor receptors VEGFR-2 and PFGFR $\beta$, was found elevated in primary TECs from human brain tumors (Würdinger et al. 2008). The miRNA miR-132 is elevated in the endothelium of human tumors and hemangioma where it is proposed to function as an angiogenic switch by suppressing 
p120RasGAP leading to Ras activation and angiogenesis stimulation (Anand et al. 2010). Taken together, high-throughput protein and gene arrays and more recently miRNA screens have been used to identify unique molecular signatures in the tumor vasculature. These studies collectively show diverse patterns of altered gene expression from different tumor types and stages of progression (see Table 1). However, no unique marker or factor in the tumor vasculature has proven suitable as a durable target for antiangiogenesis therapy.

\section{Culture Expanded TECs}

\section{Using Fresh Human Tumors}

Isolation of the first primary cultures of ECs from normal umbilical veins dramatically increased our fundamental understanding of EC biology (Gimbrone et al. 1974). Incredibly, it would be almost 30 years before the first cultures of TECs were isolated and culture expanded. One of the advantages of culture expansion is that functional in vitro assays can be performed. For example, in one of the first reports of successful isolation and culture of human TECs, Allesandri and coworkers showed that human TECs maintain their phenotype in culture, they express growth factor receptors and they are stimulated by typical EC mitogens (Alessandri et al. 1999). Bussolati showed up-regulation of angiopoietin-1, phospho-Akt and VEGF-D in cultured TECs from renal carcinoma-these TECs were also more resistant to the chemotherapeutic drug vincristine (Bussolati et al. 2003). The same group later showed that the Pax2 transcription factor is elevated in TEC (Fonsato et al. 2006). Silencing Pax2 resulted in a decrease in phospho-Akt and decreased resistance to vincristine. Notably, a recent study found no evidence for increased basal phospho-Akt in human hepatocellular carcinoma TECs, but TECs were less sensitive to 5-FU and Sorafenib (Xiong et al. 2009).

The ECs in tumors are generally classified as being "activated" or chronically inflamed. A good example is the expression of Thy-1 (an adhesion receptor for leukocytes) in tumor vessels in situ and in isolated TECs that could mediate interactions with proinflammatory cells or tumor cells (Dudley et al. 2008a; Jurisic et al. 2010). Some TECs resemble high endothelial venules (HEVs) often observed in inflamed tissues in which individual ECs have a "plump and tall" phenotype and express chemokines and receptors that mediate leukocyte trafficking (Hayasaka et al. 2010). These HEV-like "nests" have been identified in breast carcinoma and are associated with clusters of leukocytes at their margins (Tanaka et al. 1992). Although ICAMs 1 and 2 are reportedly decreased in isolated human TECs from colon carcinoma (Griffioen et al. 1996), other adhesion molecules including E-selectin (Bussolati et al. 2003) and NCAM (Bussolati et al. 2006) are overexpressed in cultured TECs from different human tumors. Constitutive expression of adhesion molecules in tumor vessels could mediate the increased tropism and trafficking of proinflammatory cells that are also proangiogenic. Adhesion molecule expression in TECs may be induced by contact with tumor cells (Haddad et al. 2009), but may persist even when cells are placed in culture suggesting a cell autonomous mechanism of regulation independent of tumor cell-mediated stimulation.

\section{Tumor Models in Mice}

Only a few laboratories have reported successful isolation and culture expansion of mouse TECs from tumor bearing mice (either xenografts or spontaneous tumors). Similar to human TECs, there are problems with contamination by tumor cells and other cell types found in the tumor stroma making it difficult to obtain pure TEC cultures. Amin reported that isolated and culture expanded TECs from implanted melanoma and breast tumors express ErbBs 1, 2 , and 4 and are stimulated to proliferate by EGF (Amin et al. 2006). Normal ECs from counterpart tissues did not express EGF-R. Other studies seem to confirm EGF-R expression by tumor blood vessels in vivo (Baker et al. 2002; Kim et al. 2003). Growth stimulation in the TEC pool by EGF-R ligands may be an alternative survival pathway beyond 


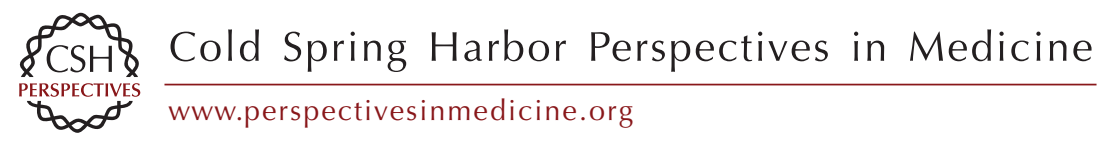

Table 1. A time line of tumor endothelial cell (TEC) isolation and characterization: 41 studies of isolated tumor endothelial cells grouped by year

\begin{tabular}{|c|c|c|c|c|c|c|c|c|c|c|}
\hline 1999 & 2000 & 2002 & 2003 & 2004 & 2005 & 2006 & 2007 & 2008 & 2009 & 2010 \\
\hline $\begin{array}{l}\text { (Alessandri } \\
\text { et al.) } \\
\text { Human } \\
\text { kidney } \\
\text { tumor }\end{array}$ & $\begin{array}{l}\text { (St. Croix } \\
\quad \text { et al.) } \\
\text { Human } \\
\text { colon } \\
\text { tumor }\end{array}$ & $\begin{array}{l}\text { (Unger et al.) } \\
\text { Human brain } \\
\text { tumor }\end{array}$ & $\begin{array}{l}\text { (Allport et al.) } \\
\text { Mouse lung } \\
\text { tumor } \\
\text { (Hoffman et al.) } \\
\text { Mouse skin } \\
\text { tumors } \\
\text { (Joyce et al.) } \\
\text { Mouse } \\
\text { pancreatic } \\
\text { tumor } \\
\text { (Bussolati et al.) } \\
\text { Human } \\
\text { kidney tumor }\end{array}$ & $\begin{array}{l}\text { (Hida et al.) } \\
\text { Mouse } \\
\text { liposarcoma } \\
\text { and melanoma } \\
\text { (Streubel et al.) } \\
\text { Human B cell } \\
\text { lymphoma } \\
\text { (Madden et al.) } \\
\text { Human brain } \\
\text { tumor } \\
\text { (Parker et al.) } \\
\text { Human breast } \\
\text { tumor } \\
\text { (Oh et al.) Rat } \\
\text { lung tumor }\end{array}$ & $\begin{array}{l}\text { (Miebach et al.) } \\
\text { Human brain } \\
\text { tumor } \\
\text { (Charalambous } \\
\text { et al.) Human } \\
\text { brain tumor }\end{array}$ & $\begin{array}{l}\text { (Amin et al.) } \\
\text { Mouse breast } \\
\text { tumor } \\
\text { (Grange et al.) } \\
\text { Human breast } \\
\text { tumor } \\
\text { (Grover et al.) } \\
\text { Human } \\
\text { prostate tumor } \\
\\
\text { (Fonsato et al.) } \\
\text { Human kidney } \\
\text { tumor } \\
\\
\text { (Bussolati et al.) } \\
\text { Human kidney } \\
\text { tumor } \\
\text { (van Beijnum } \\
\text { et al.) Human } \\
\text { colon tumor } \\
\text { (Wu et al.) } \\
\text { Human liver } \\
\text { tumor } \\
\text { (Nummer et al.) } \\
\text { Human } \\
\text { pancreatic } \\
\text { tumor }\end{array}$ & $\begin{array}{l}\text { (Seaman et al.) } \\
\text { Mouse } \\
\text { multiple } \\
\text { tumors } \\
\text { (Pen et al.) } \\
\text { Human } \\
\text { brain tumor } \\
\text { (Buckanovitch } \\
\text { et al.) } \\
\text { Human } \\
\text { ovarian } \\
\text { tumor } \\
\text { (Lu et al.) } \\
\text { Human } \\
\text { ovarian } \\
\text { tumor } \\
\\
\text { (Hellebrekers } \\
\text { et al.) } \\
\text { Human } \\
\text { colon tumor } \\
\text { (Schellerer } \\
\text { et al.) } \\
\text { Human } \\
\text { colon tumor } \\
\text { (Doublier et al.) } \\
\text { Human } \\
\text { kidney } \\
\text { tumor }\end{array}$ & $\begin{array}{l}\text { (Amin et al.) } \\
\text { Mouse } \\
\text { melanoma }\end{array}$ & $\begin{array}{l}\text { (Xiong et al.) } \\
\text { Human } \\
\text { liver tumor } \\
\\
\text { (Issa et al.) } \\
\text { Human } \\
\text { pancreatic } \\
\text { tumor } \\
\text { (Jayasinghe } \\
\text { et al.) } \\
\text { Human } \\
\text { colon } \\
\text { tumor } \\
\text { (Mazzone } \\
\text { et al.) } \\
\text { Mouse } \\
\text { multiple } \\
\text { tumors }\end{array}$ & $\begin{array}{l}\text { (Johnson et al.) } \\
\text { Mouse prostate } \\
\text { tumor } \\
\text { (You et al.) Human } \\
\text { glossal } \\
\text { lymphangioma }\end{array}$ \\
\hline
\end{tabular}

Note that references to "human, rat, or mouse" in the table denote species of origin for the TECs. For example, some studies listed in the table use human tumor cell lines implanted in mice, but the isolated TECs are of mouse origin.

This table includes only those studies where TECs were interrogated following immunomagnetic separation, laser capture microdissection, in silico subcellular fractionation, or phage display. 
the canonical VEGF/bFGF axis. Specific inhibition of EGF-R in TECs in vivo can impair angiogenesis and growth of tumor cells that do not express EGF-R (Amin et al. 2008).

A principle of antiangiogenesis therapies in cancer is that the tumor endothelium is normal and will not change over time or develop drug resistance. However, Hida reported abnormal centrosomes and aneuploid chromosomes in TECs isolated from human melanoma and liposarcoma implanted in mice (Hida et al. 2004). These chromosomal abnormalities were not clonal nor were they derived from human genetic material incorporated into mouse chromosomes. Of note, overstimulation of endothelial cultures by growth factors including bFGF and VEGF was recently reported to induce centrosome duplication in ECs (Taylor et al. 2010). On the other hand, Streubel detected primary and secondary translocations in ECs that were identical to those found in follicular lymphoma suggesting either a tumor cell of origin for TECs or sharing of DNA between tumor cells and ECs (Streubel et al. 2004). Horizontal transfer of genetic material via apoptotic bodies between tumor cells and ECs has been reported (Ehnfors et al. 2009). Loss of function of gatekeeper genes in the stroma (e.g., p53) may also underlie these cytogenetic abnormalities (Hill et al. 2005; Dudley et al. 2008b).

Our laboratory has reported unusual patterns of differentiation in TECs isolated from spontaneous prostate tumors in TRAMP (transgenic adenocarcinoma of the mouse prostate) mice. For example, prostate tumor TECs unexpectedly differentiate to form bone and cartilage (Dudley et al. 2008a). Ectopic microvascular calcification was also detected along the capillary lumens of human prostate cancers. Breast tumors are also characterized by microcalcifications in the vasculature (Tse et al. 2008). Unexpected patterns of differentiation in tumor vessels may arise as vascular cells (and other stromal cells) coevolve with tumor cells and switch their phenotype (Polyak et al. 2009). For example, lineage switches and coexpression of lymphatic, endothelial, and fibroblast markers have been observed in the blood vessels of other malignancies (Breiteneder-Geleff et al. 1999;
Wang et al. 2004). Pathophysiological conditions in the tumor microenvironment including aberrant expression of growth and differentiation factors may control the fate, differentiation, and mesenchymal transition of TECs (Verfaillie 2008). One surprising finding is that TECs appear to "remember" the tumor microenvironment from which they were isolated. For example, Ghosh showed that isolated TECs fail to reorient their actin cytoskeleton when exposed to uniaxial cyclic strain and they display greater traction forces in response to variations in ECM elasticity in vitro (Ghosh et al. 2008). These results were related to high constitutive Rho and its downstream effector ROCK in TECs. The ECM in tumors is characterized by highly crosslinked collagen resulting in a "stiffer" matrix that can alter the pattern of signaling and focal adhesions to the underlying endothelium (Levental et al. 2009). TECs may be reprogrammed or adapted to these conditions, which could account for some of the structural and functional abnormalities in the tumor vasculature.

\section{TEC ABNORMALITIES MAY CONTRIBUTE TO TUMOR PROGRESSION}

The range of morphological, cellular, and molecular abnormalities reported specifically in TECs is broad and diverse. As already noted, VEGF-A alone is sufficient to induce most of the morphological changes (tortuosity, excessive branching, and leakiness) observed in the tumor vasculature. But can these abnormalities facilitate tumor growth and progression to metastases? One can easily imagine how fragile, leaky vessels or gaps and holes in the vasculature might allow tumor cells to enter the circulation and disseminate to distant sites. For example, deficient pericyte coverage, which can lead to vessel leakiness and hemorrhage, is associated with increased metastases in human cancers and in mouse tumor models (Yonenaga et al. 2005; Xian et al. 2006). As a corollary, treatment modalities that reverse these abnormalities in the vasculature might prevent metastasis. Indeed, blood vessels in LNCap-19 tumors (derived from an androgen-independent subline of LNCap) have fewer pericytes and 
A.C. Dudley

increased tumor cell invasion compared to the parental cell line (Welén et al. 2009). Similarly, a change in TEC shape in PHD2 $2^{+/-}$mice is sufficient to improve oxygenation while suppressing tumor invasion and metastases (Mazzone et al. 2009). Jain has hypothesized that vessel leakiness impairs the delivery of chemotherapeutic drugs to the tumor site and therefore blocking VEGF might "normalize" blood flow and improve drug delivery (Jain 2005). In a mouse model, a single dose of Avastin (antiVEGF antibodies) decreased microvessel density, vessel permeability and interstitial pressure while intratumoral perfusion was improved (Dickson et al. 2007). Recent clinical studies support the concept that combining Avastin with chemotherapy can lead to improved outcomes in patients with advanced rectal cancer (Willett et al. 2007).

Heterotypic interactions and cross talk between TECs and other cell types, particularly leukocytes mobilized from the circulation, might also be affected by abnormalities in the tumor vasculature. As an example, some adhesion molecules may be decreased in the tumor vasculature allowing tumors to escape immune surveillance because of impaired interactions between T-lymphocytes and the blood vessel wall (Griffioen et al. 1996; Dirkx et al. 2006). Indeed, the penetration and efficacy of primed $\mathrm{T}$ cells for tumor immunotherapy was enhanced when proinflammatory agents that up-regulated ICAM and VCAM in the vasculature were coadministered (Garbi et al. 2004).

On the other hand, tumors resemble "wounds that never heal" and TECs may constitutively overexpress adhesion molecules for proinflammatory cells (Dvorak 1986). Thus, a perivascular positioning of leukocytes at the periphery of tumor vessels is common (Dudley et al. 2010). These proinflammatory cells express most of the endothelial survival and matrix remodeling factors required for angiogenesis. In one sense then, inflammation or activation of TEC enables the conscription of a diverse population of auxiliary cells that play a catalytic role during angiogenesis. Furthermore, proinflammatory cells, particularly macrophages, not only stimulate angiogenesis, but they may also enable metastasis (Qian and Pollard 2010). Because the endothelium acts a gatekeeper controlling the egress of proinflammatory cells into the tissue (or tumor), blocking specific interactions between TECs and the immune cell infiltrate may indirectly impair angiogenesis and metastasis. Although many of the chemokines that control leukocyte tropism are tumor cell-derived, TECs may be a direct source for many of these chemotactic factors (Butler et al. 2010).

\section{WHAT IS THE ORIGIN OF TUMOR ENDOTHELIUM?}

Where does the tumor endothelium come from? The answer to this question has been more difficult to answer than expected. For a long time, the ECs lining tumor vessels were thought to arise only by mitoses, sprouting, or simple cooption of preexisting capillaries, whereas vasculogenesis occurred only during embryonic development. However, a distorted variation of each of these processes probably generates new endothelium in tumors. There may also be additional, unexpected sources for TECs. For example, Hendrix suggests that stemlike tumor cells may transdifferentiate to form endothelium (Hendrix et al. 2003). A mesenchymal stem cell, with properties of endothelial cells, was shown to form pericytes and endothelium in hemangioma (Khan et al. 2008).

The turnover of the endothelium in normal tissues is low. It is estimated that only $0.1 \%-3 \%$ of all ECs turn over daily but this may decline with age (Schwartz and Benditt 1973). In tumors, EC turnover greatly accelerates and may be 20-2000 times the rate in normal tissues (Hobson and Denekamp 1984). In a seminal paper, Folkman showed that normal adult tissues implanted in the chick chorioallantoic membrane (CAM) did not promote neovascularization whereas implanted tumors rapidly stimulated the growth of new blood vessels from the host (Ausprunk et al. 1975). For the next 20 years, angiogenesis was considered the sole or predominate source of new endothelium in tumors. However, a report by Asahara in 1997 described putative circulating $\mathrm{CD}^{+} 4^{+} /$ 
VEGFR-2 ${ }^{+}$endothelial progenitor cells that could home to areas of damaged tissue and incorporate into sites of active angiogenesis (Asahara et al. 1997). A number of subsequent studies identified similar cells circulating in blood that were localized to sites of angiogenesis in ischemic tissues and tumors (Shi et al. 1998; Peichev et al. 2000; Lyden et al. 2001). Thus, postnatal vasculogenesis was proposed as an alternative route for new tumor blood vessels. However, hematopoietic cells (e.g., monocytes) share markers with ECs, they can be mobilized into circulation and they also home to sites of neovascularization following injury (Rafii et al. 2002; Rehman et al. 2003; Case et al. 2007). Their proximity to the blood vessel and expression of markers shared with bona fide endothelium has created confusion and discrepancies over the identification of circulating ECs in solid tumors; especially in rodents (Kerbel et al. 2008; Purhonen 2008; Yoder and Ingram 2009).

The functional differences distinguishing hematopoietic cells from bona fide endothelium are becoming clear. Yoder suggests that only the endothelial colony forming cells (ECFCs) can form vessel lumens, whereas hematopoietic cells generally do not (Yoder 2009). A minimum set of criteria for identifying ECFCs in blood or tissues was also proposed by Yoder (Yoder 2009). These same criteria should be applied for identifying ECFCs in tumors using rodent models. For example, bone marrow ablation followed by engraftment with $\mathrm{GFP}^{+}$marrow is routinely used to track circulating "ECs" in tumors-immunohistochemistry or FACS is used to identify the putative ECs (Aghi and Chiocca 2005). However, these assays provide no functional information about the nature of the recruited circulating cell type(s). Culture expansion and characterization (e.g., lumen-forming abilities when reimplanted in mice) of $\mathrm{GFP}^{+}$ECFCs from collagenase digested tumor extracts would provide definitive proof for the existence of a circulating EC for tumor angiogenesis in rodents.

Recently, the vessel wall itself has been proposed as a source for vascular endothelium because it contains subpopulations of ECs with properties similar to blood-derived ECFCs (Ingram et al. 2005). Thus, in contrast to a bone marrow origin, there may be a local reservoir of highly proliferative endothelium proximal to the tumor site. Vessel wall EPCs (VW-EPCs) are proposed to rest in a "vasculogenic zone" between the smooth muscle and advential layers at the periphery of large blood vessels (Tilki et al. 2009). No studies to date have determined whether VW-EPCs might form the majority of the angiogenesis response in tumors, if there are any unique properties in VW-EPCs that could be exploited as an antiangiogenesis strategy, or if VW-EPCs might mediate vascular rebound often observed following antiangiogenic therapies in the clinic (Bergers and Hanahan 2008; Ellis and Hicklin 2008).

\section{ANTIANGIOGENIC IS NOT ALWAYS ANTIENDOTHELIAL}

Many of the original antiangiogenic strategies in cancer were designed to be "antiendothelial" for it makes biological sense to directly target the "pipes" transporting blood, oxygen, and nutrients to a growing tumor. However, an unexpected complication is that cell-to-cell heterogeneity, acquired resistance, and a multisource origin for TECs might impinge on the success of antiendothelial strategies. Although the success and selectivity of antiangiogenesis therapies in tumors depend to some extent on there being differences in TECs compared to their counterparts, too much variation in the TEC pool can have the opposite effect. One way around this problem is to target multiple cell types simultaneously, including those now known to play auxiliary roles during tumor blood vessel formation. Pericytes, fibroblasts, and other mesenchymal-lineage cells in the stroma may be valuable indirect targets for antiangiogenesis in tumors (Loeffler et al. 2006); however, hematopoietic cells, particularly those of the myelomonocytic lineages, have recently received great attention for this purpose (Murdoch et al. 2008). The role of hematopoietic lineage cells in tumor angiogenesis and their potential as targets for antiangiogenic therapies is briefly discussed below. 
A.C. Dudley

An early clue that hematopoietic cells might facilitate angiogenesis comes from studies in the AML-1-deficient embryos. These mice lack definitive hematopoiesis and show impaired angiogenesis in the head and pericardium that can be rescued by addition of hematopoietic cells expressing ANG-1 (Takakura et al. 2000). Later and in tumors, marrow-derived inflammatory cells including neutrophils, macrophages, and mast cells were shown to provide the majority of the proangiogenic factor MMP9 during angiogenesis (Coussens et al. 2000).

In the last 10 years, a number of studies have confirmed the role of proinflammatory cells in tumor angiogenesis and have identified the molecular pathways linking inflammation and cancer (Mantovani et al. 2008). Macrophages in particular appear to promote tumor invasion, cancer initiation, and angiogenesis (Qian and Pollard 2010). Furthermore, monocytes/macrophages may create a "permissive" environment that facilitates the seeding of metastases at distant sites, even before tumor cell arrival (Kaplan et al. 2005). There appear to be tumor-specific and distinct populations of myeloid cells recruited to tumors that release angiogenic factors involved in matrix remodeling or that stimulate endothelial cells directly (Coffelt et al. 2010). For example, selective depletion of neutrophils (Nozawa et al. 2006), monocytes/macrophages (Lin et al. 2006), or TIE-2 monocytes (De Palma et al. 2005) impairs tumor growth and angiogenesis. Some myeloid lineage cells $\left(\mathrm{CD}_{11} \mathrm{~b}^{+}\right)$are mobilized by chemotherapies or radiation (Ahn and Brown 2008). Furthermore, their activity in tumors might mediate resistance to antiangiogenic therapies by stimulating vascular rebound. Indeed, Ahn and colleagues showed enhancement of radiotherapy in tumors when $\mathrm{CD}_{11} \mathrm{~b}^{+}$antibodies were administered systemically (Ahn et al. 2010). Finally, hematopoietic cells may stimulate tumor blood vessel formation in other, unexpected ways. For example, macrophages may participate during nascent

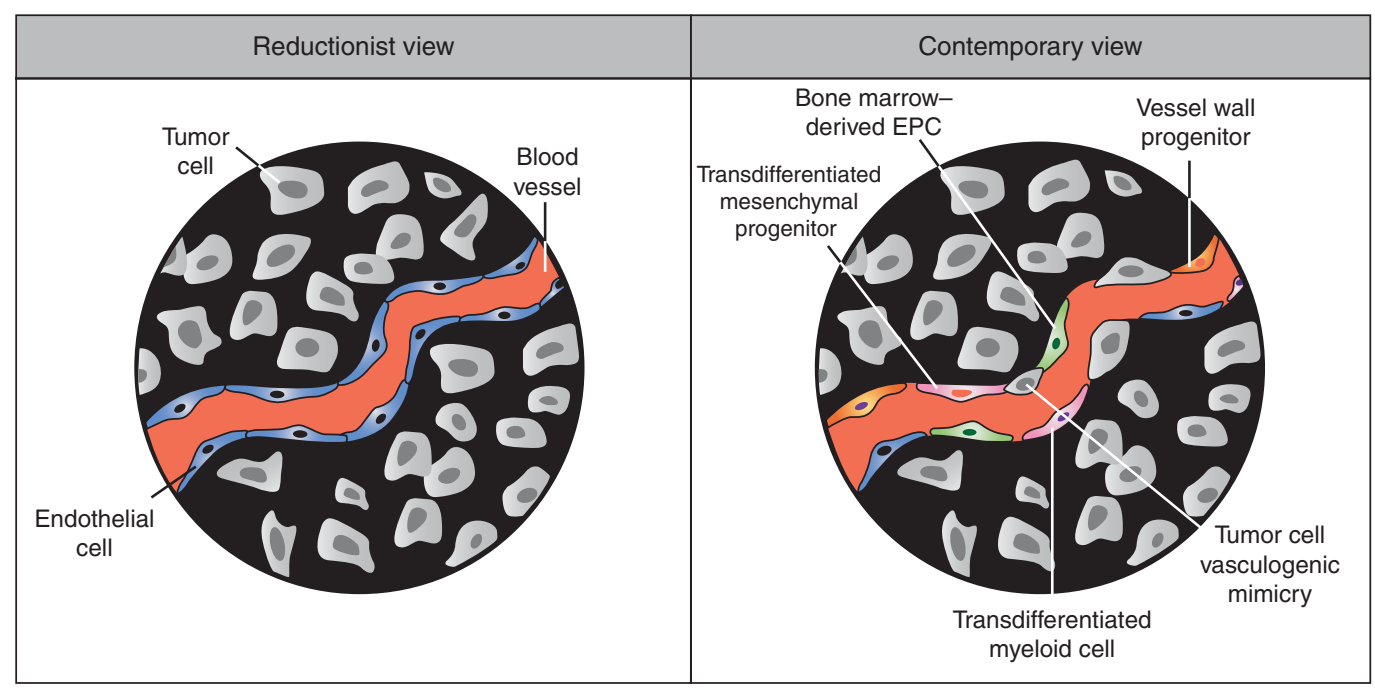

Figure 2. A reductionist versus contemporary view of tumor endothelium. In a reductionist view, all of the endothelial cells lining a tumor blood vessel are homogeneous and perhaps derived by spouting or simple cooption of nearby vessels. In the contemporary view, TECs are heterogeneous and derived from multiple sources. A composite tumor blood vessel is shown in which the endothelium may be derived by cooption or sprouting, from endothelial progenitors localized in the vessel wall, from tumor cells masquerading as endothelial cells, from marrow-derived endothelial progenitors, and from unexpected sources including transdifferentiated myeloid and mesenchymal lineage cells. Plasticity and a multisource origin may contribute to tumor blood vessel abnormalities and allow tumor vessels to evade antiangiogenic therapies. 
vessel formation by providing guidance and mechanical cues that mediate anastomosis between branching tip cells (Fantin et al. 2010). Transdifferentiation of $\mathrm{CD} 45^{+}$or $\mathrm{CD}_{11 \mathrm{~b}^{+}}$myeloid lineage cells into lumenforming endothelial-like cells in tumors was described by Bailey (Bailey et al. 2006) and by Yang (Yang et al. 2004), respectively.

\section{CONCLUSIONS AND PERSPECTIVES}

Since Dr. Judah Folkman's suggestion that tumors could be eradicated by targeting the blood vessels feeding them, the field of antiangiogenesis research in cancer has been met with some surprises. For example, tumor vessels have proven to be more complex and labile than expected and it was not predicted that TECs might be cytogenetically abnormal or derived from multiple sources (Fig. 2). Furthermore, there have been unexpected consequences of VEGF inhibition including an up-regulation of compensatory angiogenic pathways (Crawford et al. 2009) and increased metastasis in some mouse tumor models (Ebos et al. 2009). Other obstacles include heterogeneity in the vascular bed and tumor-type or stage-specific differences in TEC that could ultimately impinge on the effectiveness of the antiangiogenic therapies designed to target them (Bergers et al. 1999; Helfrich et al. 2010). There may be unique gene expression profiles in blood vessels from different regions of the tumor microenvironment or even in individual TECs of the same vessel (Chi et al. 2003). In a striking example, it was recently suggested that some tumor vessels may lose their dependence on VEGF signaling altogether theoretically rendering them refractory to VEGF inhibition (Nagy et al. 2010). Our ability to isolate and better characterize TEC from different tumors or during different stages of tumor progression should be a valuable approach for finding new targets, beyond VEGF and its receptors, in vascular cells. On the other hand, an innovative approach that includes eliminating alternative cell types (e.g., proinflammatory cells) that may not directly form new blood vessels, but nevertheless play an important role during tumor angiogenesis seems promising. Thus, TEC may be moving targets and their phenotypic diversity or multisource origin might impinge on the effectiveness of the drugs intended to target them, but there are other approaches to consider toward the goal of effective and durable antiangiogenic strategies in cancer.

\section{ACKNOWLEDGMENTS}

A.C.D. is supported by a grant from the National Cancer Institute of the National Institutes of Health (CA140708). I thank Dr. Juan M. Melero-Martin for reviewing this manuscript and Kristin Johnson for her excellent assistance with the figures.

\section{REFERENCES}

Aghi M, Chiocca EA. 2005. Contribution of bone marrowderived cells to blood vessels in ischemic tissues and tumors. Mol Ther 12: 994-1005.

Ahn G-O, Brown JM. 2008. Matrix metalloproteinase-9 is required for tumor vasculogenesis but not for angiogenesis: Role of bone marrow-derived myelomonocytic cells. Cancer Cell 13: 193-205.

Ahn G-O, Tseng D, Liao C-H, Dorie MJ, Czechowicz A, Brown JM. 2010. Inhibition of Mac-1 (CD11b/CD18) enhances tumor response to radiation by reducing myeloid cell recruitment. Proc Natl Acad Sci 107: 8363-8368.

Aird WC. 2006. Mechanisms of endothelial cell heterogeneity in health and disease. Circ Res 98: 159-162.

Aird WC. 2009. Molecular heterogeneity of tumor endothelium. Cell Tissue Res 335: 271-281.

Alessandri G, Chirivi RG, Fiorentini S, Dossi R, Bonardelli S, Giulini SM, Zanetta G, Landoni F, Graziotti PP, Turano A, et al. 1999. Phenotypic and functional characteristics of tumour-derived microvascular endothelial cells. Clin Exp Metastasis 17: 655-662.

Allport JR, Weissleder R. 2003. Murine Lewis lung carcinoma-derived endothelium expresses markers of endothelial activation and requires tumor-specific extracellular matrix in vitro. Neoplasia 5: 205-217.

Amin DN, Hida K, Bielenberg DR, Klagsbrun M. 2006. Tumor endothelial cells express epidermal growth factor receptor (EGFR) but not ErbB3 and are responsive to EGF and to EGFR kinase inhibitors. Cancer Res 66: 2173-2180.

Amin DN, Bielenberg DR, Lifshits E, Heymach JV, Klagsbrun M. 2008. Targeting EGFR activity in blood vessels is sufficient to inhibit tumor growth and is accompanied by an increase in VEGFR-2 dependence in tumor endothelial cells. Microvasc Res 76: 15-22.

Anand S, Majeti BK, Acevedo LM, Murphy EA, Mukthavaram R, Scheppke L, Huang M, Shields DJ, Lindquist JN, Lapinski PE, et al. 2010. MicroRNA-132-mediated 
A.C. Dudley

loss of p120RasGAP activates the endothelium to facilitate pathological angiogenesis. Nat Med 16: 909-914.

Arbiser JL, Raab G, Rohan RM, Paul S, Hirschi K, Flynn E, Price ER, Fisher DE, Cohen C, Klagsbrun M. 1999. Isolation of mouse stromal cells associated with a human tumor using differential diphtheria toxin sensitivity. Am J Pathol 155: 723-729.

Asahara T, Murohara T, Sullivan A, Silver M, van der Zee R, Li T, Witzenbichler B, Schatteman G, Isner JM. 1997. Isolation of putative progenitor endothelial cells for angiogenesis. Science 275: 964-967.

Ausprunk DH, Knighton DR, Folkman J. 1975. Vascularization of normal and neoplastic tissues grafted to the chick chorioallantois. Role of host and preexisting graft blood vessels. Am J Pathol 79: 597-618.

Bailey AS, Willenbring H, Jiang S, Anderson DA, Schroeder DA, Wong MH, Grompe M, Fleming WH. 2006. Myeloid lineage progenitors give rise to vascular endothelium. Proc Natl Acad Sci 103: 13156-13161.

Baker CH, Kedar D, McCarty MF, Tsan R, Weber KL, Bucana CD, Fidler IJ. 2002. Blockade of epidermal growth factor receptor signaling on tumor cells and tumor-associated endothelial cells for therapy of human carcinomas. Am J Pathol 161: 929-938.

Baluk P, Hashizume H, McDonald DM. 2005. Cellular abnormalities of blood vessels as targets in cancer. Curr Opin Genet Dev 15: 102-111.

Baudino TA, McKay C, Pendeville-Samain H, Nilsson JA, Maclean KH, White EL, Davis AC, Ihle JN, Cleveland JL. 2002. c-Myc is essential for vasculogenesis and angiogenesis during development and tumor progression. Genes Dev 16: 2530-2543.

Bergers G, Hanahan D. 2008. Modes of resistance to antiangiogenic therapy. Nat Rev Cancer 8: 592-603.

Bergers G, Javaherian K, Lo KM, Folkman J, Hanahan D. 1999. Effects of angiogenesis inhibitors on multistage carcinogenesis in mice. Science 284: 808-812.

Bhati R, Patterson C, Livasy CA, Fan C, Ketelsen D, Hu Z Reynolds E, Tanner C, Moore DT, Gabrielli F, et al. 2008. Molecular characterization of human breast tumor vascular cells. Am J Pathol 172: 1381-1390.

Breiteneder-Geleff S, Soleiman A, Kowalski H, Horvat R, Amann G, Kriehuber E, Diem K, Weninger W, Tschachler E, Alitalo K, et al. 1999. Angiosarcomas express mixed endothelial phenotypes of blood and lymphatic capillaries: Podoplanin as a specific marker for lymphatic endothelium. Am J Pathol 154: 385-394.

Buckanovich RJ, Sasaroli D, O’Brien-Jenkins A, Botbyl J, Hammond R, Katsaros D, Sandaltzopoulos R, Liotta LA, Gimotty PA, Coukos G. 2007. Tumor vascular proteins as biomarkers in ovarian cancer. J Clin Oncol 25: 852-861.

Burri PH, Hlushchuk R, Djonov V. 2004. Intussusceptive angiogenesis: Its emergence, its characteristics, and its significance. Dev Dyn 231: 474-488.

Bussolati B, Deambrosis I, Russo S, Deregibus MC, Camussi G. 2003. Altered angiogenesis and survival in human tumor-derived endothelial cells. FASEB J 17: 1159-1161.

Bussolati B, Grange C, Bruno S, Buttiglieri S, Deregibus MC, Tei L, Aime S, Camussi G. 2006. Neural-cell adhesion molecule (NCAM) expression by immature and tumor- derived endothelial cells favors cell organization into capillary-like structures. Exp Cell Res 312: 913-924.

Butler JM, Kobayashi H, Rafii S. 2010. Instructive role of the vascular niche in promoting tumour growth and tissue repair by angiocrine factors. Nat Rev Cancer 10: 138-146.

Case J, Mead LE, Bessler WK, Prater D, White HA, Saadatzadeh MR, Bhavsar JR, Yoder MC, Haneline LS, Ingram DA. 2007. Human $\mathrm{CD} 34^{+}$AC133 ${ }^{+}$VEGFR-2 ${ }^{+}$cells are not endothelial progenitor cells but distinct, primitive hematopoietic progenitors. Exp Hematol 35: 1109-1118.

Cassoni P, Marrocco T, Bussolati B, Allia E, Munaron L, Sapino A, Bussolati G. 2006. Oxytocin induces proliferation and migration in immortalized human dermal microvascular endothelial cells and human breast tumorderived endothelial cells. Mol Cancer Res 4: 351-359.

Chang YS, di Tomaso E, McDonald DM, Jones R, Jain RK, Munn LL. 2000. Mosaic blood vessels in tumors: Frequency of cancer cells in contact with flowing blood. Proc Natl Acad Sci 97: 14608-14613.

Chappell JC, Taylor SM, Ferrara N, Bautch VL. 2009. Local guidance of emerging vessel sprouts requires soluble Flt-1. Dev Cell 17: 377-386.

Charalambous C, Pen LB, Su YS, Milan J, Chen TC, Hofman FM. 2005. Interleukin-8 differentially regulates migration of tumor-associated and normal human brain endothelial cells. Cancer Res 65: 10347-10354.

Chi J-T, Chang HY, Haraldsen G, Jahnsen FL, Troyanskaya OG, Chang DS, Wang Z, Rockson SG, van de Rijn M, Botstein D, et al. 2003. Endothelial cell diversity revealed by global expression profiling. Proc Natl Acad Sci 100: 10623-10628.

Coffelt SB, Lewis CE, Naldini L, Brown JM, Ferrara N, De Palma M. 2010. Elusive identities and overlapping phenotypes of proangiogenic myeloid cells in tumors. Am J Pathol 176: 1564-1576.

Coussens LM, Tinkle CL, Hanahan D, Werb Z. 2000. MMP-9 supplied by bone marrow-derived cells contributes to skin carcinogenesis. Cell 103: 481-490.

Crawford Y, Kasman I, Yu L, Zhong C, Wu X, Modrusan Z, Kaminker J, Ferrara N. 2009. PDGF-C mediates the angiogenic and tumorigenic properties of fibroblasts associated with tumors refractory to anti-VEGF treatment. Cancer Cell 15: 21-34.

Cullen M, Seaman S, Chaudhary A, Yang MY, Hilton MB, Logsdon D, Haines DC, Tessarollo L, St Croix B. 2009 Host-derived tumor endothelial marker 8 promotes the growth of melanoma. Cancer Res 69: 6021-6026.

De Palma M, Venneri MA, Galli R, Sergi Sergi L, Politi LS, Sampaolesi M, Naldini L. 2005. Tie2 identifies a hematopoietic lineage of proangiogenic monocytes required for tumor vessel formation and a mesenchymal population of pericyte progenitors. Cancer Cell 8: 211-226.

De Val S, Black BL. 2009. Transcriptional control of endothelial cell development. Dev Cell 16: 180-195.

Dickson PV, Hamner JB, Sims TL, Fraga CH, Ng CYC, Rajasekeran S, Hagedorn NL, McCarville MB, Stewart CF Davidoff AM. 2007. Bevacizumab-induced transient remodeling of the vasculature in neuroblastoma xenografts results in improved delivery and efficacy of systemically administered chemotherapy. Clin Cancer Res 13: 3942-3950. 
Dirkx AEM, oude Egbrink MGA, Castermans K, van der Schaft DWJ, Thijssen VLJL, Dings RPM, Kwee L, Mayo KH, Wagstaff J, Bouma-ter Steege JCA, et al. 2006. Antiangiogenesis therapy can overcome endothelial cell anergy and promote leukocyte-endothelium interactions and infiltration in tumors. FASEB J 20: 621-630.

di Tomaso E, Capen D, Haskell A, Hart J, Logie JJ, Jain RK, McDonald DM, Jones R, Munn LL. 2005. Mosaic tumor vessels: Cellular basis and ultrastructure of focal regions lacking endothelial cell markers. Cancer Res 65: 57405749.

Doublier S, Ceretto M, Lupia E, Bravo S, Bussolati B, Camussi G. 2007. The proangiogenic phenotype of tumor-derived endothelial cells is reverted by the overexpression of platelet-activating factor acetylhydrolase. Clin Cancer Res 13: 5710-5718.

Dudley AC, Khan ZA, Shih S-C, Kang S-Y, Zwaans BMM, Bischoff J, Klagsbrun M. 2008a. Calcification of multipotent prostate tumor endothelium. Cancer Cell 14: 201-211.

Dudley AC, Shih S-C, Cliffe AR, Hida K, Klagsbrun M. 2008b. Attenuated p53 activation in tumour-associated stromal cells accompanies decreased sensitivity to etoposide and vincristine. Br J Cancer 99: 118-125.

Dudley AC, Udagawa T, Melero-Martin JM, Shih S-C, Curatolo A, Moses MA, Klagsbrun M. 2010. Bone marrow is a reservoir for pro-angiogenic myelomonocytic cells but not endothelial cells in spontaneous tumors. Blood 116: 3367-3371.

Dvorak HF. 1986. Tumors: Wounds that do not heal. Similarities between tumor stroma generation and wound healing. N Engl J Med 315: 1650-1659.

Ebos JML, Lee CR, Cruz-Munoz W, Bjarnason GA, Christensen JG, Kerbel RS. 2009. Accelerated metastasis after short-term treatment with a potent inhibitor of tumor angiogenesis. Cancer Cell 15: 232-239.

Ehnfors J, Kost-Alimova M, Persson NL, Bergsmedh A, Castro J, Levchenko-Tegnebratt T, Yang L, Panaretakis T, Holmgren L. 2009. Horizontal transfer of tumor DNA to endothelial cells in vivo. Cell Death Differ 16: 749-757.

Ellis LM, Hicklin DJ. 2008. Pathways mediating resistance to vascular endothelial growth factor-targeted therapy. Clin Cancer Res 14: 6371-6375.

Fantin A, Vieira JM, Gestri G, Denti L, Schwarz Q, Prykhozhij S, Peri F, Wilson SW, Ruhrberg C. 2010. Tissue macrophages act as cellular chaperones for vascular anastomosis downstream of VEGF-mediated endothelial tip cell induction. Blood 116: 829-840.

Fonsato V, Buttiglieri S, Deregibus MC, Puntorieri V, Bussolati B, Camussi G. 2006. Expression of Pax2 in human renal tumor-derived endothelial cells sustains apoptosis resistance and angiogenesis. Am J Pathol 168: 706-713.

Garbi N, Arnold B, Gordon S, Hämmerling GJ, Ganss R. 2004. CpG motifs as proinflammatory factors render autochthonous tumors permissive for infiltration and destruction. J Immunol 172: 5861-5869.

Gerhardt H, Golding M, Fruttiger M, Ruhrberg C, Lundkvist A, Abramsson A, Jeltsch M, Mitchell C, Alitalo K, Shima D, et al. 2003. VEGF guides angiogenic sprouting utilizing endothelial tip cell filopodia. J Cell Biol 161: $1163-1177$.
Ghosh K, Thodeti CK, Dudley AC, Mammoto A, Klagsbrun M, Ingber DE. 2008. Tumor-derived endothelial cells exhibit aberrant Rho-mediated mechanosensing and abnormal angiogenesis in vitro. Proc Natl Acad Sci 105: 11305-11310.

Gimbrone MA, Cotran RS, Folkman J. 1974. Human vascular endothelial cells in culture. Growth and DNA synthesis. J Cell Biol 60: 673-684.

Grange C, Bussolati B, Bruno S, Fonsato V, Sapino A, Camussi G. 2006. Isolation and characterization of human breast tumor-derived endothelial cells. Oncol Rep 15: $381-386$.

Griffioen AW, Damen CA, Martinotti S, Blijham GH, Groenewegen G. 1996. Endothelial intercellular adhesion molecule- 1 expression is suppressed in human malignancies: The role of angiogenic factors. Cancer Res 56: 1111-1117.

Grover AC, Tangrea MA, Woodson KG, Wallis BS, Hanson JC, Chuaqui RF, Gillespie JW, Erickson HS, Bonner RF, Pohida TJ, et al. 2006. Tumor-associated endothelial cells display GSTP1 and RAR $\beta 2$ promoter methylation in human prostate cancer. J Trans Med 4: 13 .

Haddad O, Chotard-Ghodsnia R, Verdier C, Duperray A. 2009. Tumor cell/endothelial cell tight contact upregulates endothelial adhesion molecule expression mediated by NFкB: Differential role of the shear stress. Exp Cell Res 316: 615-626.

Halder C, Ossendorf C, Maran A, Yaszemski M, Bolander ME, Fuchs B, Sarkar G. 2009. Preferential expression of the secreted and membrane forms of tumor endothelial marker 7 transcripts in osteosarcoma. Anticancer Res 29: 4317-4322.

Hashizume H, Baluk P, Morikawa S, McLean JW, Thurston G, Roberge S Jain RK, McDonald DM. 2000. Openings between defective endothelial cells explain tumor vessel leakiness. Am J Pathol 156: 1363-1380.

Hayasaka H, Taniguchi K, Fukai S, Miyasaka M. 2010. Neogenesis and development of the high endothelial venules that mediate lymphocyte trafficking. Cancer Sci 101: 2302-2308.

Helfrich I, Scheffrahn I, Bartling S, Weis J, Von Felbert V, Middleton M, Kato M, Ergun S, Schadendorf D. 2010. Resistance to antiangiogenic therapy is directed by vascular phenotype, vessel stabilization, and maturation in malignant melanoma. J Exp Med 207: 491-503.

Hellebrekers DMEI, Melotte V, Viré E, Langenkamp E, Molema G, Fuks F, Herman JG, Van Criekinge W, Griffioen AW, van Engeland M. 2007. Identification of epigenetically silenced genes in tumor endothelial cells. Cancer Res 67: 4138-4148.

Hellström M, Gerhardt H, Kalén M, Li X, Eriksson U, Wolburg H, Betsholtz C. 2001. Lack of pericytes leads to endothelial hyperplasia and abnormal vascular morphogenesis. J Cell Biol 153: 543-553.

Hellström M, Phng L-K, Hofmann JJ, Wallgard E, Coultas L, Lindblom P, Alva J, Nilsson A-K, Karlsson L, Gaiano N, et al. 2007. Dll4 signalling through Notch1 regulates formation of tip cells during angiogenesis. Nature 445: 776-780.

Hendrix MJC, Seftor EA, Hess AR, Seftor REB. 2003. Vasculogenic mimicry and tumour-cell plasticity: Lessons from melanoma. Nat Rev Cancer 3: 411-421. 
A.C. Dudley

Hida K, Hida Y, Amin DN, Flint AF, Panigrahy D, Morton CC, Klagsbrun M. 2004. Tumor-associated endothelial cells with cytogenetic abnormalities. Cancer Res 64: 8249-8255.

Hill R, Song Y, Cardiff RD, Van Dyke T. 2005. Selective evolution of stromal mesenchyme with p53 loss in response to epithelial tumorigenesis. Cell 123: 1001-1011.

Hirschi KK, D'Amore PA. 1996. Pericytes in the microvasculature. Cardiovasc Res 32: 687-698.

Hobson B, Denekamp J. 1984. Endothelial proliferation in tumours and normal tissues: Continuous labelling studies. Br J Cancer 49: 405-413.

Hoffman JA, Giraudo E, Singh M, Zhang L, Inoue M, Porkka K, Hanahan D, Ruoslahti E. 2003. Progressive vascular changes in a transgenic mouse model of squamous cell carcinoma. Cancer Cell 4: 383-391.

Hynes RO. 2009. The extracellular matrix: Not just pretty fibrils. Science 326: 1216-1219.

Ingram DA, Mead LE, Moore DB, Woodard W, Fenoglio A, Yoder MC. 2005. Vessel wall-derived endothelial cells rapidly proliferate because they contain a complete hierarchy of endothelial progenitor cells. Blood 105: 2783-2786.

Issa Y, Nummer D, Seibel T, Müerköster SS, Koch M, Schmitz-Winnenthal F-H, Galindo L, Weitz J, Beckhove P, Altevogt P. 2009. Enhanced L1CAM expression on pancreatic tumor endothelium mediates selective tumor cell transmigration. J Mol Med 87: 99-112.

Jain RK. 2005. Normalization of tumor vasculature: An emerging concept in antiangiogenic therapy. Science 307: $58-62$.

Jayasinghe C, Simiantonaki N, Michel-Schmidt R, Kirkpatrick CJ. 2009. Comparative study of human colonic tumor-derived endothelial cells (HCTEC) and normal colonic microvascular endothelial cells (HCMEC): Hypoxia-induced sVEGFR-1 and sVEGFR-2 levels. Oncol Rep 21: 933-939.

Jin S-W, Patterson C. 2009. The opening act: Vasculogenesis and the origins of circulation. Arterioscler Thromb Vasc Biol 29: 623-629.

Johnson CS, Chung I, Trump DL. 2010. Epigenetic silencing of CYP24 in the tumor microenvironment. J Steroid Biochem Mol Biol 121: 338-342.

Joyce JA, Laakkonen P, Bernasconi M, Bergers G, Ruoslahti E, Hanahan D. 2003. Stage-specific vascular markers revealed by phage display in a mouse model of pancreatic islet tumorigenesis. Cancer Cell 4: 393-403.

Jurisic G, Iolyeva M, Proulx ST, Halin C, Detmar M. 2010. Thymus cell antigen 1 (Thyl, CD90) is expressed by lymphatic vessels and mediates cell adhesion to lymphatic endothelium. Exp Cell Res 316: 2982-2992.

Kalluri R. 2003. Basement membranes: Structure, assembly and role in tumour angiogenesis. Nat Rev Cancer 3: 422-433.

Kamoun WS, Chae S-S, Lacorre DA, Tyrrell JA, Mitre M, Gillissen MA, Fukumura D, Jain RK, Munn LL. 2010. Simultaneous measurement of RBC velocity, flux, hematocrit and shear rate in vascular networks. Nat Methods 7: 655-660.

Kaplan RN, Riba RD, Zacharoulis S, Bramley AH, Vincent L, Costa C, MacDonald DD, Jin DK, Shido K, Kerns SA, et al. 2005. VEGFR1-positive haematopoietic bone marrow progenitors initiate the pre-metastatic niche. Nature 438: $820-827$.

Kerbel RS, Benezra R, Lyden DC, Hattori K, Heissig B, Nolan DJ, Mittal V, Shaked Y, Dias S, Bertolin F, et al. 2008. Endothelial progenitor cells are cellular hubs essential for neoangiogenesis of certain aggressive adenocarcinomas and metastatic transition but not adenomas. Proc Natl Acad Sci 105: E54 (author reply E55).

Khan ZA, Boscolo E, Picard A, Psutka S, Melero-Martin JM, Bartch TC, Mulliken JB, Bischoff J. 2008. Multipotential stem cells recapitulate human infantile hemangioma in immunodeficient mice. J Clin Invest 118: 2592-2599.

Kim S-J, Uehara H, Karashima T, Shepherd DL, Killion JJ, Fidler IJ. 2003. Blockade of epidermal growth factor receptor signaling in tumor cells and tumor-associated endothelial cells for therapy of androgen-independent human prostate cancer growing in the bone of nude mice. Clin Cancer Res 9: 1200-1210.

Klagsbrun M, Eichmann A. 2005. A role for axon guidance receptors and ligands in blood vessel development and tumor angiogenesis. Cytokine Growth Factor Rev 16: 535-548.

Konerding MA, Malkusch W, Klapthor B, van Ackern C, Fait E, Hill SA, Parkins C, Chaplin DJ, Presta M, Denekamp J. 1999. Evidence for characteristic vascular patterns in solid tumours: Quantitative studies using corrosion casts. Br J Cancer 80: 724-732.

Lacaud G, Keller G, Kouskoff V. 2004. Tracking mesoderm formation and specification to the hemangioblast in vitro. Trends Cardiovasc Med 14: 314-317.

Lancrin C, Sroczynska P, Stephenson C, Allen T, Kouskoff V, Lacaud G. 2009. The haemangioblast generates haematopoietic cells through a haemogenic endothelium stage. Nature 457: 892-895.

Lee HK, Bae HR, Park HK, Seo IA, Lee EY, Suh DJ, Park HT. 2005. Cloning, characterization and neuronal expression profiles of tumor endothelial marker 7 in the rat brain. Brain Res Mol Brain Res 136: 189-198.

Levental KR, Yu H, Kass L, Lakins JN, Egeblad M, Erler JT, Fong SFT, Csiszar K, Giaccia A, Weninger W, et al. 2009. Matrix crosslinking forces tumor progression by enhancing integrin signaling. Cell 139: 891-906.

Lin EY, Li J-F, Gnatovskiy L, Deng Y, Zhu L, Grzesik DA, Qian H, Xue X-n, Pollard JW. 2006. Macrophages regulate the angiogenic switch in a mouse model of breast cancer. Cancer Res 66: 11238-11246.

Loeffler M, Krüger JA, Niethammer AG, Reisfeld RA. 2006. Targeting tumor-associated fibroblasts improves cancer chemotherapy by increasing intratumoral drug uptake. J Clin Invest 116: 1955-1962.

Lu C, Bonome T, Li Y, Kamat AA, Han LY, Schmandt R, Coleman RL, Gershenson DM, Jaffe RB, Birrer MJ, et al. 2007. Gene alterations identified by expression profiling in tumor-associated endothelial cells from invasive ovarian carcinoma. Cancer Res 67: 1757-1768.

Lyden D, Hattori K, Dias S, Costa C, Blaikie P, Butros L, Chadburn A, Heissig B, Marks W, Witte L, et al. 2001. Impaired recruitment of bone-marrow-derived endothelial and hematopoietic precursor cells blocks tumor angiogenesis and growth. Nat Med 7: 1194-1201. 
MacFadyen J, Savage K, Wienke D, Isacke CM. 2007. Endosialin is expressed on stromal fibroblasts and CNS pericytes in mouse embryos and is downregulated during development. Gene Expr Patterns 7: 363-369.

Madden SL, Cook BP, Nacht M, Weber WD, Callahan MR, Jiang Y, Dufault MR, Zhang X, Zhang W, Walter-Yohrling J, et al. 2004. Vascular gene expression in nonneoplastic and malignant brain. Am J Pathol 165: 601-608.

Maniotis AJ, Folberg R, Hess A, Seftor EA, Gardner LM, Pe'er J, Trent JM, Meltzer PS, Hendrix MJ. 1999. Vascular channel formation by human melanoma cells in vivo and in vitro: Vasculogenic mimicry. Am $J$ Pathol 155: 739-752.

Mantovani A, Allavena P, Sica A, Balkwill F. 2008. Cancerrelated inflammation. Nature 454: 436-444.

Mazzone M, Dettori D, Leite de Oliveira R, Loges S, Schmidt T, Jonckx B, Tian Y-M, Lanahan AA, Pollard P, Ruiz de Almodovar C, et al. 2009. Heterozygous deficiency of PHD2 restores tumor oxygenation and inhibits metastasis via endothelial normalization. Cell 136: 839-851.

McDonald DM, Choyke PL. 2003. Imaging of angiogenesis: From microscope to clinic. Nat Med 9: 713-725.

McDonald DM, Munn L, Jain RK. 2000. Vasculogenic mimicry: How convincing, how novel, and how significant? Am J Pathol 156: 383-388.

Melero-Martin J, De Obaldia M, Kang S-Y, Khan Z, Yuan L, Oettgen P, Bischoff J. 2008. Engineering robust and functional vascular networks in vivo with human adult and cord blood-derived progenitor cells. Circ Res 103: 194.

Merlo LMF, Pepper JW, Reid BJ, Maley CC. 2006. Cancer as an evolutionary and ecological process. Nat Rev Cancer 6 : 924-935.

Miebach S, Grau S, Hummel V, Rieckmann P, Tonn J-C, Goldbrunner RH. 2006. Isolation and culture of microvascular endothelial cells from gliomas of different WHO grades. J Neurooncol 76: 39-48.

Murdoch C, Muthana M, Coffelt SB, Lewis CE. 2008. The role of myeloid cells in the promotion of tumour angiogenesis. Nat Rev Cancer 8: 618-631.

Nagy JA, Dvorak AM, Dvorak HF. 2007. VEGF-A and the induction of pathological angiogenesis. Annu Rev Pathol 2: $251-275$.

Nagy JA, Chang S-H, Dvorak AM, Dvorak HF. 2009. Why are tumour blood vessels abnormal and why is it important to know? Br J Cancer 100: 865-869.

Nagy JA, Chang S-H, Shih S-C, Dvorak AM, Dvorak HF. 2010. Heterogeneity of the tumor vasculature. Semin Thromb Hemost 36: 321-331.

Nozawa H, Chiu C, Hanahan D. 2006. Infiltrating neutrophils mediate the initial angiogenic switch in a mouse model of multistage carcinogenesis. Proc Natl Acad Sci 103: $12493-12498$.

Nummer D, Suri-Payer E, Schmitz-Winnenthal H, Bonertz A, Galindo L, Antolovich D, Koch M, Büchler M, Weitz J, Schirrmacher V, et al. 2007. Role of tumor endothelium in $\mathrm{CD}^{+} \mathrm{CD}^{+} 5^{+}$regulatory $\mathrm{T}$ cell infiltration of human pancreatic carcinoma. J Natl Cancer Inst 99: 1188-1199.

Oh P, Li Y, Yu J, Durr E, Krasinska KM, Carver LA, Testa JE, Schnitzer JE. 2004. Subtractive proteomic mapping of the endothelial surface in lung and solid tumours for tissue-specific therapy. Nature 429: 629-635.
Opavsky R, Haviernik P, Jurkovicova D, Garin MT, Copeland NG, Gilbert DJ, Jenkins NA, Bies J, Garfield S, Pastorekova S, et al. 2001. Molecular characterization of the mouse Tem1/endosialin gene regulated by cell density in vitro and expressed in normal tissues in vivo. J Biol Chem 276: 38795-38807.

Padera TP, Stoll BR, Tooredman JB, Capen D, di Tomaso E, Jain RK. 2004. Pathology: Cancer cells compress intratumour vessels. Nature 427: 695.

Parker BS, Argani P, Cook BP, Liangfeng H, Chartrand SD, Zhang M, Saha S, Bardelli A, Jiang Y, St Martin TB, et al. 2004. Alterations in vascular gene expression in invasive breast carcinoma. Cancer Res 64: 7857-7866.

Patan S, Munn LL, Jain RK. 1996. Intussusceptive microvascular growth in a human colon adenocarcinoma xenograft: A novel mechanism of tumor angiogenesis. Microvasc Res 51: 260-272.

Patan S, Tanda S, Roberge S, Jones RC, Jain RK, Munn LL. 2001. Vascular morphogenesis and remodeling in a human tumor xenograft: Blood vessel formation and growth after ovariectomy and tumor implantation. Circulation Research 89: 732-739.

Peichev M, Naiye, AJ, Pereira D, Zhu Z, Lane WJ, Williams M, Oz MC, Hicklin DJ, Witte L, Moore MA, et al. 2000. Expression of VEGFR-2 and AC133 by circulating human CD34 ${ }^{+}$cells identifies a population of functional endothelial precursors. Blood 95: 952-958.

Pen A, Moreno MJ, Martin J, Stanimirovic DB. 2007. Molecular markers of extracellular matrix remodeling in glioblastoma vessels: Microarray study of laser-captured glioblastoma vessels. Glia 55: 559-572.

Polyak K, Haviv I, Campbell IG. 2009. Co-evolution of tumor cells and their microenvironment. Trends Genet 25: $30-38$.

Purhonen PSS. 2008. Reply to Kerbel, et al. EPCs are again claimed to be essential in yet other models despite the irreproducibility of the original experiments introducing them. Proc Natl Acad Sci 105: E55.

Qian B-Z, Pollard JW. 2010. Macrophage diversity enhances tumor progression and metastasis. Cell 141: 39-51.

Rafii S, Lyden D, Benezra R, Hattori K, Heissig B. 2002. Vascular and haematopoietic stem cells: Novel targets for anti-angiogenesis therapy? Nat Rev Cancer 2: 826-835.

Rehman J, Li J, Orschell CM, March KL. 2003. Peripheral blood "endothelial progenitor cells" are derived from monocyte/macrophages and secrete angiogenic growth factors. Circulation 107: 1164-1169.

Schellerer VS, Croner RS, Weinländer K, Hohenberger W, Stürzl M, Naschberger E. 2007. Endothelial cells of human colorectal cancer and healthy colon reveal phenotypic differences in culture. Lab Invest 87: 1159-1170.

Schwartz SM, Benditt EP. 1973. Cell replication in the aortic endothelium: A new method for study of the problem. Lab Invest 28: 699-707.

Seaman S, Stevens J, Yang MY, Logsdon D, Graff-Cherry C, St Croix B. 2007. Genes that distinguish physiological and pathological angiogenesis. Cancer Cell 11: 539-554.

Shi Q, Rafii S, Wu MH, Wijelath ES, Yu C, Ishida A, Fujita Y, Kothari S, Mohle R, Sauvage LR, et al. 1998. Evidence for circulating bone marrow-derived endothelial cells. Blood 92: $362-367$. 
A.C. Dudley

St Croix B, Rago C, Velculescu V, Traverso G, Romans KE Montgomery E, Lal A, Riggins GJ, Lengauer C, Vogelstein B, et al. 2000. Genes expressed in human tumor endothelium. Science 289: 1197-1202.

Streubel B, Chott A, Huber D, Exner M, Jäger U, Wagner O, Schwarzinger I. 2004. Lymphoma-specific genetic aberrations in microvascular endothelial cells in B-cell lymphomas. N Engl J Med 351: 250-259.

Sullivan R, Graham CH. 2007. Hypoxia-driven selection of the metastatic phenotype. Cancer Metastasis Rev 26: 319-331.

Takakura N, Watanabe T, Suenobu S, Yamada Y, Noda T, Ito Y, Satake M, Suda T. 2000. A role for hematopoietic stem cells in promoting angiogenesis. Cell 102: 199-209.

Tanaka H, Hori M, Ohki T. 1992. High endothelial venule and immunocompetent cells in typical medullary carcinoma of the breast. Virchows Arch A Pathol Anat Histopathol 420: 253-261.

Taylor SM, Nevis KR, Park HL, Rogers GC, Rogers SL, Cook JG, Bautch VL. 2010. Angiogenic factor signaling regulates centrosome duplication in endothelial cells of developing blood vessels. Blood 116: 3108-3117.

Tilki D, Hohn H-P, Ergün B, Rafii S, Ergün S. 2009. Emerging biology of vascular wall progenitor cells in health and disease. Trends Mol Med 15: 501-509.

Tse GM, Tan P-H, Pang ALM, Tang APY, Cheung HS. 2008. Calcification in breast lesions: Pathologists' perspective. J Clin Pathol 61: 145-151.

Unger RE, Oltrogge JB, von Briesen H, Engelhardt B, Woelki U, Schlote W, Lorenz R, Bratzke H, Kirkpatrick CJ. 2002. Isolation and molecular characterization of brain microvascular endothelial cells from human brain tumors. In Vitro Cell Dev Biol Anim 38: 273-281.

van Beijnum JR, Dings RP, van der Linden E, Zwaans BMM, Ramaekers FCS, Mayo KH, Griffioen AW. 2006. Gene expression of tumor angiogenesis dissected: Specific targeting of colon cancer angiogenic vasculature. Blood 108: 2339-2348.

Verfaillie CM. 2008. Bony endothelium: Tumor-mediated transdifferentiation? Cancer Cell 14: 193-194.

Walter-Yohrling J, Morgenbesser S, Rouleau C, Bagley R, Callahan M, Weber W, Teicher BA. 2004. Murine endothelial cell lines as models of tumor endothelial cells. Clin Cancer Res 10: 2179-2189.

Wang H-W, Trotter MWB, Lagos D, Bourboulia D, Henderson S, Mäkinen T, Elliman S, Flanagan AM, Alitalo K, Boshoff C. 2004. Kaposi sarcoma herpesvirus-induced cellular reprogramming contributes to the lymphatic endothelial gene expression in Kaposi sarcoma. Nat Genet 36: 687-693.

Warren BA, Shubik P, Wilson R, Garcia H, Feldman R. 1978. The microcirculation in two transplantable melanomas of the hamster. I. In vivo observations in transparent chambers. Cancer Lett 4: 109-116.
Welén K, Jennbacken K, Tesan T, Damber J-E. 2009. Pericyte coverage decreases invasion of tumour cells into blood vessels in prostate cancer xenografts. Prostate Cancer Prostatic Dis 12: 41-46.

Willett CG, Duda DG, di Tomaso E, Boucher Y, Czito BG, Vujaskovic Z, Vlahovic G, Bendell J, Cohen KS, Hurwitz HI, et al. 2007. Complete pathological response to bevacizumab and chemoradiation in advanced rectal cancer. Nat Clin Pract Oncol 4: 316-321.

Wu LQ, Zhang WJ, Niu JX, Ye LY, Yang ZH, Grau GE, Lou JN. 2008. Phenotypic and functional differences between human liver cancer endothelial cells and liver sinusoidal endothelial cells. J Vasc Res 45: 78-86.

Würdinger T, Tannous BA, Saydam O, Skog J, Grau S, Soutschek J, Weissleder R, Breakefield XO, Krichevsky AM. 2008. miR-296 regulates growth factor receptor overexpression in angiogenic endothelial cells. Cancer Cell 14: 382-393.

Xian X, Håkansson J, Ståhlberg A, Lindblom P, Betsholtz C, Gerhardt H, Semb H. 2006. Pericytes limit tumor cell metastasis. J Clin Invest 116: 642-651.

Xiong Y-Q, Sun H-C, Zhang W, Zhu X-D, Zhuang P-Y, Zhang J-B, Wang L, Wu W-Z, Qin L-X, Tang Z-Y. 2009. Human hepatocellular carcinoma tumor-derived endothelial cells manifest increased angiogenesis capability and drug resistance compared with normal endothelial cells. Clin Cancer Res 15: 4838-4846.

Yang L, DeBusk LM, Fukuda K, Fingleton B, Green-Jarvis B, Shyr Y, Matrisian LM, Carbone DP, Lin PC. 2004. Expansion of myeloid immune suppressor $\mathrm{Gr}+\mathrm{CD} 1 \mathrm{~b}+$ cells in tumor-bearing host directly promotes tumor angiogenesis. Cancer Cell 6: 409-421.

Yoder MC. 2009. Defining human endothelial progenitor cells. J Thromb Haemost 7: 49-52.

Yoder MC, Ingram DA. 2009. Endothelial progenitor cell: Ongoing controversy for defining these cells and their role in neoangiogenesis in the murine system. Curr Opin Hematol 16: 269-273.

Yoder MC, Mead LE, Prater D, Krier TR, Mroueh KN, Li F, Krasich R, Temm CJ, Prchal JT, Ingram DA. 2007. Redefining endothelial progenitor cells via clonal analysis and hematopoietic stem/progenitor cell principals. Blood 109: 1801-1809.

Yonenaga Y, Mori A, Onodera H, Yasuda S, Oe H, Fujimoto A, Tachibana T, Imamura M. 2005. Absence of smooth muscle actin-positive pericyte coverage of tumor vessels correlates with hematogenous metastasis and prognosis of colorectal cancer patients. Oncology 69: 159-166.

You L, Wu M, Chen Y, Xu G, Wei J, Li Q, Song A, Zhao L, Li S, Han Z, et al. 2010. Isolation and characterization of lymphatic endothelial cells from human glossal lymphangioma. Oncol Rep 23: 105-111. 


\section{$\&_{\mathrm{CSH}}^{\infty} \&$ Cold Spring Harbor

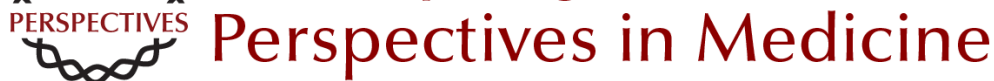

\section{Tumor Endothelial Cells}

Andrew C. Dudley

Cold Spring Harb Perspect Med 2012; doi: 10.1101/cshperspect.a006536 originally published online October 18, 2011

\section{Subject Collection Angiogenesis}

Extracellular Matrix Regulation of Vascular Morphogenesis, Maturation, and Stabilization George E. Davis and Scott S. Kemp

Endothelial Cell-Pericyte Interactions in the Pathogenesis of Cerebral Cavernous Malformations (CCMs) Wang Min and Jenny Huanjiao Zhou

Lymphatic Clearance and Pump Function Jerome W. Breslin

Platelets and (Lymph)angiogenesis Harvey G. Roweth and Elisabeth M. Battinelli

Modeling Brain Vasculature Immune Interactions In Vitro Ruth Lyck, Hideaki Nishihara, Sidar Aydin, et al.

Human Endothelial Colony-Forming Cells Juan M. Melero-Martin

\section{The Beauty and Complexity of Blood Vessel} Patterning

Victoria L. Bautch and Yoh-suke Mukouyama

Endothelialitis, Microischemia, and

Intussusceptive Angiogenesis in COVID-19 Steven J. Mentzer, Maximilian Ackermann and Danny Jonigk
Regulation of the Blood-Brain Barrier in Health and Disease

Cara C. Rada, Kanako Yuki, Jie Ding, et al.

Targeting Angiogenesis via Resolution of

Inflammation

Abigail G. Kelly and Dipak Panigrahy

Notch Signaling in the Vasculature: Angiogenesis and Angiocrine Functions

Sana S. Hasan and Andreas Fischer

Signal Transduction and Gene Regulation in the

Endothelium

Michel V. Levesque and Timothy Hla

Buttons and Zippers: Endothelial Junctions in

Lymphatic Vessels

Peter Baluk and Donald M. McDonald

Endothelial Cell Fate Determination: A Top Notch Job in Vascular Decision-Making

L.A. Naiche, Stephanie R. Villa and Jan K. Kitajewski

Leukocyte Trafficking in Lymphatic Vessels Aline Bauer, Hazal Tatliadim and Cornelia Halin

Lymphatic Tissue and Organ Engineering for In Vitro Modeling and In Vivo Regeneration Anna M. Kolarzyk, Gigi Wong and Esak Lee

For additional articles in this collection, see http://perspectivesinmedicine.cshlp.org/cgi/collection/ 